\title{
持続可能な上下水道システム構築へ向けた 総合評価手法
}

\author{
木村 昌弘 1 伊藤禎彦 2 \\ 1正会員（侏クボ夕 鉄管事業部（テ556-8601大阪市浪速区敷津1丁目2番47号） \\ E-mail:masahiro_kimura@nk.kubota.co.jp \\ 2正会員 京都大学大学院 工学研究科（T615-8540 京都市西京区京都大学桂Cクラスター） \\ E-mail:itoh@urban.env.kyoto-u.ac.jp
}

\begin{abstract}
地球環境の保全、流域の水循環の健全性, 水道の安定性・安全性などを貨幣価值で統合的に評価するため 「流域水資産健全度指数」という新しい指標を用いた上下水道システムの総合評価手法を提案した. その指標によるモデル流域での総合評価では, 下水の処理水を河川に還流するケ-スが最も高い評価となり， 地球温暖化対策としては自律分散型のシステムが有効との結論を得た.
\end{abstract}

Key Words :sustainability, water circulation, comprehensive evaluation, water and sewage systems

\section{1. はじめに}

20世紀型の経済発展がもたらした地球環境問題は,今や 我々人類の将来の前に大きく立ちはだかろうとしている. 2007年2月のIPCC報告では,地球温暖化が経済発展に よる温暖化ガスによるものであることが科学的に裏づけさ れたとして大きな警鐘が鳴らされた. 限りある水資源と手 ルギーに支えられた現在の上下水道事業においても,長期 的な視野での環境戦略が必要であり,そのためには地球 環境や人口減少等を見据えてシステムを再構築してくた めの新たな指標が必要となる. 本研究は,以上の視点から 「流域水資産健全度指数」という新たな指標を用いて流域 の水循環の健全性や水道の安定性·安全性などを貨幣価 值で統合的に評価する総合評価手法を提案する．また,検 討のモデルとして大阪府南部の河川流域を選定し,設定 の異なる上下水道システムについてその評価を試みたも のである.

\section{2. 評価手法と指標設定の考え方}

\section{(1)総合評価手法}

これまで環境を含む総合的な評価は,大規模な事業の 実施や企業活動,国や府県のマク口な環境の評価など多 くの分野で研究され実施に移されてきた. 環境アセスメ小は, 事業の環境評価分野で発展し,現在では政策決定段階か ら評価しようとする戦略的アセスメンけ実施に移されつつあ る.ライフサイクルアセスメント(LCA)は,企業の商品製造分野か
ら出発したもので国際規格化されたことで,上下水道を含 む広い分野で,政策立案などより高次な目的での利用に 発展しつつある. また環境会計は、企業の環境活動の評 価手法として発展し,環境だけでなく社会・経済を含むパー フォーマンス評価の反映へと移行しつつある. マクロ経済 の分野では、グリーンGNPといわれる環境経済統合勘定 の導入が進められ,そのほかにも国の「総合的環境指標」 など国や地域の豊かさや幸福度を評価する指標の検討 や導入も行われている.

これらの評価の項目と手法は多種多様で分類方法も多 数あるが,国内外の事例を指標の数で分類すると,単一指 標と指標群に分けられる. 単一指標は、全体の理解が容 易で計画全体のコンセプトを広く伝えやすくなる反面,指 標の統合による,個別情報の損失が大きく,単一化により， 一面的な評価になるおそれがある. 指標群では,個別情 報の損失が少なく,多面的な評価が可能な分,全体の分か りやすさが儀牲になり,全体の評価・コンセプトが曖昧にな ると指摘されている ${ }^{1)}$. 利用分野や目的によって指標の項 目や数は判断されなければならないが,今後の持続可能 なシステムの方向性へ判断するには,環境項目だけでなく 安全性や安定性といったシステムそのものの評価を含め ることが不可欠なことから,環境指標も含め,個々の指標群 とともにそれらを統合評価する単一指標が必要である.こ のような指標の統合化に関して,これまでLCAでは影響項 目の特性化結果に,環境問題の重み付けによって統合化 を試みる問題比較型といわれる手法を中心に開発が進め られてきた.この代表的な重み付けの方法には,アンケー 卜などを利用して支払い意思額などを問う方法や,環境目 
標とその達成度を指標として利用する DtT 法, 専門家など が重み付けするパネル法などがある. しかし,近年では問 題比較型の統合化手法についての問題点が指摘され,欧 州を中心として新たな被害算定型と呼ばれる統合化手法

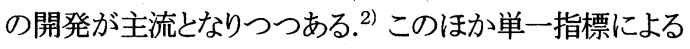
環境全般の総合評価方法として土地面積やエネルギー消費 量,物質の総使用量などで環境影響を間接的に表現する 「エコロジカルフットプリトやや「エコロジカル・リュクサック」,「エコスペー 对, 目標值と現状值との差が環境影響を顕示するものと仮 定した基準比較法などがある. また地域計画の分野では, 住民アンケートを通じて環境の質の重み付けなどを行い 地域環境の総合評価が行われてきた.

上水道の分野では,これまで事業の評価には普及率や 経営収支などが,また環境評価には有収率や水質,電力使 用量などの指標が個々の事業体で独自に用いられてきた. 最近では環境会計を導入する事業体も増加してきている. こうした中で,平成 17 年に「水道事業ガイドライン」が㫼定 され,水道の安心に関わる水源の保全,水質管理や環境に かかる温暖化防止,健全な水循環などの 137 項目の業務 指標が導入され,統一した基準で事業を評価できるように なった. これにより全国レベルでの個々の課題の他事業 体との相対的評価が可能になったが,これは事業体単位 での指標群による評価指標であり,絶対的な評価や総合 的評価,さらには流域全体としての水循環や下水道との関 連評価などの課題は依然として残されている. また,流域 の水環境の総合評価に関する最近の研究では,環境·経 済統合勘定を適用した評価 ${ }^{4}$ やウオーターサプライフットプリン 卜指標を用いた研究5)などがあるが,これらはマクロな評価 指標であり,治水,利水,環境といった個々の評価には適さ ない. 上下水道分野では,エコデザインによる評価 ${ }^{6}$, $\mathrm{LCA}$ を用いた上下水道の評価 ${ }^{7)}$,8)やアセットマネージメントを 導入した水道施設の維持管理手法の研究 9)も進められて いるが,環境影響だけでなくシステムの安全性・安定性な どの社会的影響や維持管理コストなどの経済的影響を含 めて統一的に総合評価できる手法には至っていない.

こうた背景を下に本研究では,持続可能な上下水道シ ステムの構築といら視点から,地球環境や流域の治水,利 水,環境, 上下水道シ $\bar{\top} \bar{\tau} \Delta$ 安全性,安定性を全て貨幣価値 で評価し,ライクサイルルス（LCC)を含めて「流域水資産健全 度指数」といら新しい指標で全体を統合的に評価する手 法を提案する.

\section{(2)評価指標と評価項目}

総合的な指標には,環境効率性や環境容量,物質フ口 一,貨幣価值などを用いる方法があるが,貨幣価值ですべ てを統一する研究事例は少ない.

「経済価值化は環境影響により受ける被害量、例えば人
間の損失余命を貨幣価值で評価することで得られる.こ のような評価は,倫理的な問題や代表的な環境価値を測 ることの困難さなど多くの論点が存在するが,費用対便益 分析や環境会計など,様々なコミュニケーションツールとし て活用できるため,その利用性は医療経済や環境経済,政 策評価において高く評価されている.」 ${ }^{10}$ とされており,評価 の手法として,ここでは,実用性や汎用性,住民の理解しや すさを考慮し,貨幣評価を用いることとしたものである.こ の金銭化に当たっては,最近の研究成果を最大限に活用 し,LCIA 分野で世界的な潮流々なりつつある被害算定法 を中心に基淮比較法や環境経済評価法の一種である再 生費用法や便益移転等を用いた。

\section{表-1 事項別の課題と今回の評価指標}

\begin{tabular}{|c|c|c|}
\hline & 事項別の諸課題 & 今回の評価指標 \\
\hline \multirow{6}{*}{$\begin{array}{l}\text { 地球環境 } \\
\text { 1 }\end{array}$} & 地球温暖化 & (3) $\mathrm{CO}_{2}$ \\
\hline & 森林の减少 & (1)自然緑地 \\
\hline & 土袞劣化砂漠化 & (1)自然緑地 \\
\hline & 生物多様性の減少 & (1)自然緑地 \\
\hline & 水資源不足 & (2)渇水被害 \\
\hline & エネルギー資源枯渇 & (3)エネルギー \\
\hline \multirow{8}{*}{$\begin{array}{l}\text { 水循環 } \\
2 \\
2\end{array}$} & 通常時河川流量减少 & (1)平常時流量 \\
\hline & 洪水被害ポデンシャル増大 & (1)洪水流量 \\
\hline & 非常時用水確保困難 & (2)渇水被害 \\
\hline & 水質問題の発生 & (1)河川水質 \\
\hline & 地下水位の低下 & (1)平常時流量 \\
\hline & ヒートアイランド現象 & (1)湖沼等水面 \\
\hline & 生態系への悪影響 & (1)河川自然度 \\
\hline & 親水機能の低下 & (1)河川親水度 \\
\hline \multirow{5}{*}{$\begin{array}{l}\text { 水道 } \\
3\end{array}$} & 安心 & (2)安全性 \\
\hline & 安定 & (2)安定性 \\
\hline & 持続 & (4)LCC \\
\hline & 環境 & (3) $\mathrm{CO}_{2}$,エネルギー- \\
\hline & 国際 & - \\
\hline \multirow{4}{*}{\multicolumn{2}{|c|}{$\begin{array}{l}\text { 1環境白書 }(\mathrm{H} 12)^{11)} \\
\text { 2)健全な水循環系構築のための計画づ } \\
\text { くりに向けで'3) } \\
\text { 3/水道ビジョン }\end{array}$}} & (1)河川・流域指標 \\
\hline & & (2)水道指標 \\
\hline & & (3)地球環境指標 \\
\hline & & (4)LCC指標 \\
\hline
\end{tabular}

\section{(3)指標の選定}

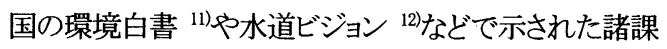
題を基に,表一1に示すとおり,(1)河川流域指標として平常 時流量,洪水流量,河川水質,自然緑地,湖沼等水面,(2)水 道指標として安定性(渴水、事故、地震)、安全性(発ガン, クリプトスポリシューム,水源水質事故) (3)地球環境指標として $\mathrm{CO}_{2}$, エネルギー,(4)ライフサイクルコスト訃して上下水道 LCC を選 定し指標とした. 


\section{3. 河川及ひ流域評価指標}

健全な水循環系構築に関する省庁連絡会議の報告 ${ }^{13)}$ において,今日の水循環系の問題点として挙げられた要 因より,河川指標 5 項目, 流域指標 2 項目を選定した.

\section{(1) 河川指標}

河川状況を示寸指標は,文献 ${ }^{14)}$ 等を基に平常時の流量 $\mathrm{Q}_{0}$, 洪水流量 $\mathrm{Q}_{\mathrm{f}}$, 水質 $(C O D)$, 自然度,近接度とした.

\section{a) 平常時の流量 $Q_{0}$}

河川の流況を示す指標には,豊,平,低,渴水流量等があ るが,ここでは平常時に住民が接する機会を考慮して年 間に185日下回らない流量である平水流量を用いた. 平 常時の流量の算定は式(3-1)に示す水収支法を用いた.ま た目標流量は,親水性や魚類の生息環境より設定して,こ れを確保するために必要な費用を指標とした。

$$
Q_{0}=A_{n}\left(R-E_{n}\right) / 0.365-Q_{f}-Q_{\text {out }}+Q_{\text {in }}
$$

ここで,

$\mathrm{Q}_{0}$ :平常時の流量 $\left(\mathrm{m}^{3} /\right.$ 日)

$\mathrm{Q}_{\mathrm{f}}$ : 降雨流出流量 $\left(\mathrm{m}^{3} /\right.$ 日)

$$
\left.\left(Q f=f_{n} \cdot A_{n} \cdot\left(R-E_{n}\right)\right) / 0.365\right)
$$

$\mathrm{A}_{\mathrm{n}}: \mathrm{n}$ 流域面積 $\mathrm{km}^{2}, \mathrm{f}_{\mathrm{n}}$ :降雨(表面)流出率

$\mathrm{R}:$ 年間降雨量 $\left(\mathrm{mm} /\right.$ 年) $, \mathrm{E}_{\mathrm{n}}:$ 年間蒸発散量 $(\mathrm{mm} /$ 年)

$\mathrm{Q}_{\text {out }}$ : 河川からの取水量十地下水等の下水管への漏出量 $\mathrm{Q}_{\mathrm{in}}$ : 生活排水等流入量 + 下水処理水還流量+水道漏水量

なお下水道への漏水量は,下水処理場に流入する污水 流量と水道使用量分（有収水量）の差とし,モデル計算で は,対象流域の実績(15) より下水処理量の $10 \%$ とした. 生 活排水等の流入量は,生活・業務営業用等の水道使用水の 下水道未整備地区からの河川への流入量を表す.下水処 理水還流量は,下水処理場で処理した水を再び河川に還 流させる流量である. また蒸発散量は,Thornthwaite式に より年間蒸発能を求め,地目毎の抵抗係数 ${ }^{16)}$ 乗じて地目 別の值を求めた（表-2）.

表-2 地目別蒸発散量·流出率

\begin{tabular}{|l|l|l|l|l|l|l|}
\hline & 森林 & 農地 & 宅地 & 水面 & 道路 & その他 \\
\hline $\begin{array}{l}\text { 蒸 発 量 } \mathrm{E} \\
(\mathrm{mm} / \text { 年 })\end{array}$ & 640 & 640 & 160 & 890 & 320 & 530 \\
\hline 流出率f & 0.3 & 0.2 & 0.7 & 1 & 0.9 & 0.5 \\
\hline
\end{tabular}

目標流量 $\mathrm{Q}_{\mathrm{G}}$ は,三浦ら ${ }^{17}$ の検討等を参考に表-3に示す 親水活動の容易さや魚類の生息環境より設定した. なお平 常時の水深·流速の計算は等流式を用いた.

平常時流量指標 $\mathrm{D}_{\mathrm{Q}_{0}}$ は、次式で求めた。

$$
\mathrm{D}_{\mathrm{Q}_{0}}=\mathrm{J}_{\mathrm{Q}_{0}} \times\left(\mathrm{Q}_{\mathrm{G}}-\mathrm{Q}_{0}\right)
$$

ここにJ $\mathrm{J}_{Q_{0}}$ は,平常時の水量不足に対する費用原単位で,こ
れまで大阪府営水道が関与してきた安威川ダム,紀ノ川大 堰,丹生ダム,日吉ダム等 6 事業の水源開発単価 ${ }^{18)}$ の平均 值 61 億円 $/\left(\right.$ 万 $\mathrm{m}^{3} /$ 日)を耐用年数 50 年で除した 1.2 億円/ 年/(万融淐)を用いた。

表-3 河川の目標水深と流速

\begin{tabular}{|l|l|l|l|}
\hline & & 水深 $(\mathrm{m})$ & 流速 $(\mathrm{m} / \mathrm{S})$ \\
\hline 魚類の生息 & コイ・フナ & $0.15-0.2$ & 0.3 \\
\hline \multirow{2}{*}{$\begin{array}{l}\text { 川遊び等の } \\
\text { 親水活動 } \\
\text { レベル }\end{array}$} & 浅くて困難 & $\sim 0.1$ & \\
\cline { 2 - 4 } & 幼児が遊べる & $\sim 0.2$ & $\sim 0.2$ \\
\cline { 2 - 4 } & 危険で困難 & 0.4 以上 & 0.5 以上 \\
\hline
\end{tabular}

\section{b)河川水質 $\mathrm{q}(\mathrm{cos})$}

水道水源水質 (水質管理目標設定項目)としてこれまで COD と対応する過マンガン酸かリ消費量が用いられてき たこと,また,農業(水稲)用水の水質基準としても COD が 用いられていること,住民参加の点からパック方式など簡 易な方法で測定することができること,更に、底生生物と水 質の関係で COD が EPT 值(カゲロウ、カワゲラ、トビケラ の種の合計值)との相関が最も高い14)ことなどを踏まえ，湖 沼等の COD 評価など流域全体の水質との整合性も総合 的に勘案して,ここでは河川水質として COD を用いること にした.

河川水質 $\mathrm{q}_{(\mathrm{COD})}(\mathrm{mg} / \mathrm{L})$ )算定には,流出負荷と流出流量 の比で求める原単位法 ${ }^{19)}$ を用い次式で求めた.

$$
\mathrm{q}_{(\mathrm{COD})}=\mathrm{Lt} / \mathrm{Q} \times 1000 \times \mathrm{f}_{\alpha}
$$

ここで, $\mathrm{Q}:$ 平均流量 $\left(\mathrm{m}^{3} /\right.$ 日), $\mathrm{f}_{\alpha}$ : 負荷流達率

$\mathrm{Lt}$ : 総流出負荷 (Lp: 点源負荷 $+\mathrm{L}_{\mathrm{n}}$ : 面源負荷) $(\mathrm{kg} /$ 日)

$\mathrm{L}_{\mathrm{p}}$ ：点源負荷 $(\mathrm{kg} /$ 日) (生活排水十産業排水十畜産系 排水十下水処理水)

生活排水原単位は,文献 ${ }^{19)}$ で示された 1 人 1 日当たり の污濁負荷量と浄化槽の排出負荷量原単位より,合併浄 化槽: $8 \mathrm{~g} /$ 人/日,単独浄化槽: 21 (浄化槽 $4+$ 雑排水 17 ) $\mathrm{g} /$ 人 /日, 乙尿処理: 17 (雑排水 17 ) $\mathrm{g} /$ 人/日,下水処理水の水 質は COD $5 \mathrm{mg} / \mathrm{L}$ (高度処理水実績)とした. また,産業排 水は業種別原単位 ( $\mathrm{g}$ /百万円) に出荷額を乗じて,また畜 産系は,家畜の原単位 $(\mathrm{g} /$ 頭/日) と飼育頭数より求めた。

$\mathrm{L}_{\mathrm{n}}$ : 面源負荷 [原単位 $\left(\mathrm{kg} / \mathrm{km}^{2} /\right.$ 日) $\times$ 面積 $\left(\mathrm{km}^{2}\right)$ ]

COD の面源負荷流出原単位は,表-4に示すわが国の 既往の調查報告値の平均値 ${ }^{20)}$ を用いた。

表-4 地目別 COD 面源負荷流出原単位 $\left(\mathrm{kg} / \mathrm{km}^{2} /\right.$ 日)

\begin{tabular}{|l|l|l|l|l|l|}
\hline 森林 & 農地 & 宅地 & 水面 & 道路 & その他 \\
\hline 28 & 4.9 & 39.6 & 0 & 39.6 & 22.25 \\
\hline
\end{tabular}

平常時水質については,流出負荷は流出流量に比例 するとして,式(3-3)で求められる平均水質を用いた. 
負荷流達率 $\mathrm{f}_{\alpha}$ は,比流量 $\mathrm{q}(\mathrm{Q} / \mathrm{A})\left(\mathrm{m}^{3} /\right.$ 日 $\left./ \mathrm{km}^{2}\right)$ と年間負 荷との関係 ${ }^{19)} よ り 、$ 次式を作成した.

$$
\mathrm{f}_{\alpha}=\text { 比流量 } \mathrm{q} \times 0.0002
$$

水質指標ししての水質嫌悪度 $\mathrm{D}_{\mathrm{q}}$ は次式により算定した.

$$
D_{\mathrm{q}}=\mathrm{J}_{\mathrm{q}} \times\left(\mathrm{q}_{\mathrm{g}}-\mathrm{q}_{\mathrm{o}}\right) \times \mathrm{Q}_{\mathrm{o}}
$$

ここで, $\mathrm{q}_{\mathrm{g}}$ : 目標水質, $\mathrm{q}_{\mathrm{o}}$ : 河川水質, $\mathrm{J}_{\mathrm{q}}$ : 水質価值原単位 $\mathrm{J}_{\mathrm{q}}$ は河川の水質 $(\mathrm{COD})$ が $1 \mathrm{mg} / \mathrm{L}$ 変化することによる水質 価值の変化を示すものである. 水質とその価値に関して は,水道水 $\left(100\right.$ 円 $\left.\left./ \mathrm{m}^{3}: \mathrm{COD} \quad 0.6 \mathrm{mg} / \mathrm{L}\right)\right)$ と農業用水 $(4$ 円 $\left./ \mathrm{m}^{3}: \mathrm{COD} 20 \mathrm{mg} / \mathrm{L}\right)$ 単価と水質を用いて式(3-6)に示 す関係式を求めた. この式から COD1g当たりの価值が5 円となることから $\mathrm{J}_{q}: 5$ 円 $/ \mathrm{g}(\mathrm{COD}) \times 365$ 日/年と設定できる.

$$
\mathrm{Y}=-4.95 \mathrm{X}+103
$$

ここに,Y:水質価値 $\left(\right.$ 円 $\left./ \mathrm{m}^{3}\right), \mathrm{X}$ :水質 $(\mathrm{COD}, \mathrm{mg} / \mathrm{L})$

なお,水道水の水質は,大阪府村野浄水場水質害績 ${ }^{21)}$ 基に設定し,農業用水の単価は,表-5に示寸全国の水利 負担額 ${ }^{22)}$,23) と農業用水使用量 ${ }^{22)}$ より設定した。

\begin{tabular}{|l|r|}
\hline 全国農用地 (田十普通畑)面積 & 3760.0 (千 ha) \\
\hline 1 アール当たり水利負担額 & $6412.0($ 円/ア ール/年) \\
\hline 全国水利負担額 & $2410.9($ 億円/年) \\
\hline 全国農業用水使用量 & $557.0($ 億m3/年) \\
\hline 農業用水単価 & $4.3($ 円 $/ \mathrm{m} 3)$ \\
\hline
\end{tabular}

表-5 農業用水単価算定内訳

今回検討モデルとした西除川流域における過去 20 年 間の年間降雨 ${ }^{24)}$, 気温 ${ }^{25)}$, 土地利用 ${ }^{26)}$, 面源・点源負荷量 等 ${ }^{27)}$ の資料を収集して(図-1 参照),今回の計算モデルを 用いて平常時流量と水質を計算し,実測値と比較すること によってそれらの妥当性を検討した.

西除川の流量観測値は,大阪府流量観測報告 ${ }^{28)}$ に記 載された布忍橋地点 (流域面積 $39 \mathrm{~km}^{2}$ ) の平水流量値を 用いた. 計算值は最下流部(流域面積 $47 \mathrm{~km}^{2}$ ) の計算結 果に流域比を乗じた值とした. 水質観測値については大 阪府域河川等水質調査報告書 ${ }^{29}$ に記載された西除川流 量観測地点の近傍にある宮橋の観測記録を用いた. 結 果を,図-2, 図-3に示すが,これらのモデルの適応性がほ ぼ確認できた。

\section{c) 洪水流量 $Q_{f}$}

洪水流量(河川の治水能力以上の流量)の算定は,広く中 小河川計画に用いられている合理式(式(3-7))を用いた.

$$
Q_{f}=1 / 3.6\left(f_{a} \times A_{a} \times r_{a}+f_{n} \times A_{n} \times r_{n}\right)
$$

ここに, $\mathrm{f}_{\mathrm{a}}=0.9, \mathrm{f}_{\mathrm{n}}=0.6$ : 都市域, 自然域の洪水流出係数,

$A_{a}, A_{n}$ : 都市域, 自然域の流域面積 $\left(\mathrm{km}^{2}\right)$,

$r_{a}, r_{n}$ ： " , " の洪水到達時間 $\left(t_{a}, t_{n}\right)$ 内降雨強度 $(\mathrm{mm} / \mathrm{h})$ 洪水到達時間は,土木研究所の式 ${ }^{30}(3-8)$ を用いた.

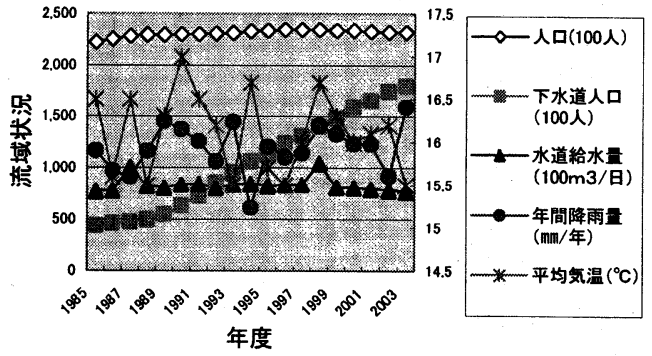

图-1 西除川流域状況の推移

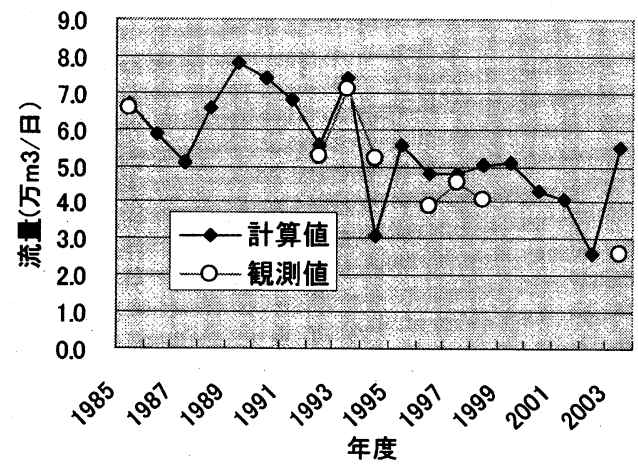

图-2 西除川流量の観測值と計算値の比較

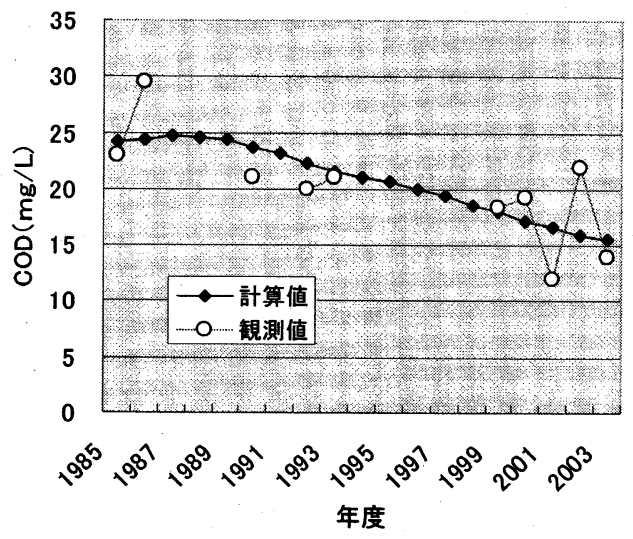

图-3 西除川水質の観測值と計算結果の比較

$$
\mathrm{t}_{\mathrm{a}}=1.8\left(\mathrm{~L} / \mathrm{I}^{1 / 2}\right)^{0.7} \quad \mathrm{t}_{\mathrm{n}}=12.6\left(\mathrm{~L} / \mathrm{I}^{\mathrm{1} / 2}\right)^{0.7}
$$

ここに,L:流域長 $\mathrm{km}, \mathrm{I}:$ 斜面勾配

降雨強度式は,大阪府流域下水道計画 ${ }^{31)}$ で用いられて いるシャーマン型の式(3-9)を用いた。

$$
r(t)=\alpha \cdot t^{-\beta}
$$

大阪管区気象台の過去 30 年 (1971-2000)のデータによる 年間の時間最大,日最大降雨強度より, 各降雨確率に対 する $\alpha, \beta$ を求めた. (表一6) 
一洪水指標としての洪水被害度Dfは次式で算定した.

$$
D_{\mathrm{f}}=J_{\mathrm{f}} \int Q_{\mathrm{f}} \times f\left(Q_{\mathrm{f}}\right) d Q
$$

ここで $\mathrm{J}_{\mathrm{f}} \mathrm{Q}_{\mathrm{f}}$ による洪水被害額, $\mathrm{f}\left(\mathrm{Q}_{\mathrm{f}}\right): \mathrm{Q}_{\mathrm{f}}$ の発生確率

$\mathrm{J}_{\mathrm{f}}$ は西除川上流部にある狭山池ダムの年平均被害軽減 額 ${ }^{32)}$ と洪水調節流量より0.1億円 $/ \mathrm{m}^{3} / \mathrm{s}$ とた.

表-6 降雨の発生確率之降雨強度式の各定数

\begin{tabular}{|l|r|r|r|r|}
\hline 降雨確率 & \multicolumn{1}{|c|}{ 時間 $(\mathrm{mm} / \mathrm{h})$} & \multicolumn{1}{|c|}{1 日 $(\mathrm{mm} / \mathrm{h})$} & \multicolumn{1}{l|}{$\alpha$} & \multicolumn{1}{l|}{$\beta$} \\
\hline $1 / 10$ & 53.8 & 5.7 & 970 & 0.706 \\
\hline $1 / 100$ & 75 & 7.9 & 1362 & 0.708 \\
\hline
\end{tabular}

\section{d)水辺への接近度、河川自然度}

水辺への近づき難さを示すものとして,図-4に示す護 岸の法面勾配や天端幅員を用い,近づきやすい理想の断 面形とするために必要な用地を確保する年間費用を指標 とし次式で算定した.

$$
\text { Dwac }=\mathrm{J}_{\mathrm{a}} \Sigma[(3-\mathrm{I}) \mathrm{hw}+(3 \mathrm{~m}-\mathrm{Br})] \Delta \mathrm{L}
$$

ここに $\mathrm{hw}$ : 水面功の高さ $(\mathrm{m}), \mathrm{I}:$ の面勾配, $\mathrm{Br}$ : 河川側 道幅 $(\mathrm{m}), \Delta \mathrm{L}$ 区間距離 $(\mathrm{m}), \mathrm{J}_{\mathrm{a}}$ : 用地単価 $\left(\right.$ 円 $/ \mathrm{m}^{2} /$ 年)

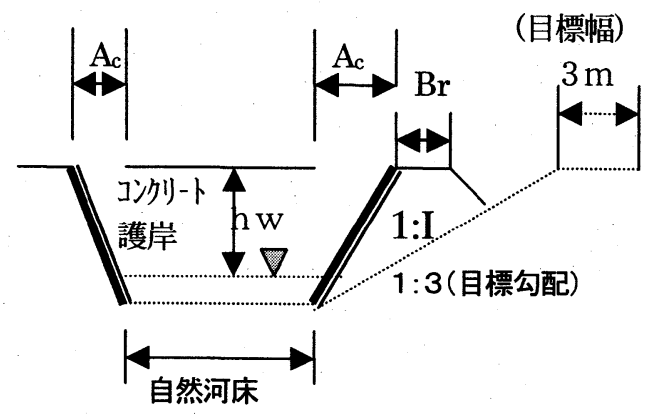

図-4河川非自然指標算定模式図

河川の自然度を示すものとして,矢板やコンクリートなどの人 工構造物で固められた河川に本来の自然河川機能を確 保するためには,代替となる新たな用地が必要と考え,そ の確保費用(年間費用)を指標とし,次式で算定した.

$$
D_{m}=J_{n} \times A_{c}
$$

ここに Ac:河川敷内に非自然的な構造物が占める面積, $J_{\mathrm{n}}$ :用地単価 $\left(\right.$ 円 $/ \mathrm{m}^{2} /$ 年)

\section{(2)流域指標}

\section{a) 自然緑地}

流域の健全度に関する指標としては,流域内の自然域 (森林と農地面積)の価値 Nw を取り上げた. 年間の単位 面積当たりの価値(原単位)は,森林と農地の多目的機能 評価 ${ }^{33)}$ で示された全国の森林と農地の年間価値を,洪水 調節等河川指標之重複する評価項目は除き, 全国のそれ
ぞれの面積で除して設定した(表-7).

表一7 森林·農地の多目的価値

\begin{tabular}{|c|c|}
\hline 森林 評価額 & 農地 評価額 \\
\hline $\begin{array}{c}\mathrm{CO}_{2} \text { 吸収: } \\
12391 \text { 億円/年 }\end{array}$ & 気候緩和: $: 87$ 億円/年 \\
\hline 化石燃料: 2261 億円/年 & \\
\hline 保健リクリエーション: & \\
\hline 22256 億円/年 & 保健休養·安らぎ: \\
& 23758 億円/年 \\
\hline 計:36908 億円/年 & 計: 23845 億円/年 \\
\hline 森林面積: 2512 万 $\mathrm{ha}$ & 耕地面積: 470 万 $\mathrm{ha}$ \\
\hline 森林価値原単位 & 農地価値原単位 \\
0.15 億円 $/ \mathrm{km}^{2} /$ 年 & 0.51 億円 $/ \mathrm{km}^{2} /$ 年 \\
\hline
\end{tabular}

$$
\mathrm{Nw}=\mathrm{Jw}_{\mathbf{q}} \times \mathrm{Aw}+\mathrm{Ja}_{\mathbf{q}} \times \mathrm{Aa}
$$

ここに $A_{w}$ : 森林面積 $\left(\mathrm{km}^{2}\right), \mathrm{A}_{\mathrm{a}}$ :農地面積 $\left(\mathrm{km}^{2}\right)$

$\mathrm{JW}_{\mathrm{z}}$ (森林価値原単位) $: 0.15$ 億円 $/ \mathrm{km}^{2} /$ 年

$\mathrm{Ja}_{\mathbf{4}}$ (農地価值原単位) $: 0.51$ 億円 $/ \mathrm{km}^{2} /$ 年

\section{b)湖沼等水面}

湖沼等の水面にも森林や農地と同様に多目的価值が あり,水質の良い水面には農地の気候緩和や保健休養・ 安らぎ機能と同様な効用が考えられる.ここでは水質によ りその価值が異なることから,次式で表されるものとした.

$$
\mathrm{Iw}=\mathrm{Jwa} \times \mathrm{f}\left(\mathrm{q}_{\mathrm{p}}\right) \times \text { Awa }
$$

ここに,Jwa: 水面価值原単位 $\left(0.51\right.$ 億円 $/ \mathrm{km}^{2} /$ 年), Awa: 水面面積 $\left(\mathrm{km}^{2}\right), \mathrm{q}_{\mathrm{p}}$ 湖沼等の水質 (CODmg/L) $\mathrm{f}\left(\mathrm{q}_{\mathrm{p}}\right)$ : 水質価值指数で, 式(3-6)を用いて, $\mathrm{q}_{\mathrm{p}}=2 \mathrm{mg} / \mathrm{L}$ で $\mathrm{f}=1, \mathrm{q}_{\mathrm{p}}=20 \mathrm{mg} / \mathrm{L}$ で $\mathrm{f}=0$ とすれば, 次式で表される.

$$
\mathrm{f}\left(\mathrm{q}_{\mathrm{p}}\right)=\left(-4.95 \mathrm{q}_{\mathrm{p}}+103\right) / 93.1
$$

\section{4. 水道評価指標}

水道ビジョン ${ }^{12)} に$ 示された政策目標である「安全」「安 定」,「持続」,「環境」,「国際」から水道指標として安定性(3 項目)と安全性(2項目)を用いた.

\section{（1）安定性指標}

\section{a) 渴水断水リスク指標 (Dr)}

渴水の発生確率と給水制限量,被害度等を基に被害り スク指標を算定した.

水の価値曲線 $\mathrm{C}(\mathrm{q})$ は, 1 人 1 日平均給水量qo では 100 円 $/ \mathrm{m}^{3}$ の価値とし,断水で 33,000 円/日/人の被害が生じる として式(4-1)を用いた. ${ }^{13)}$

$$
\mathrm{C}(\mathrm{v})=\mathrm{a} \cdot \exp (-\mathrm{b} \cdot \mathrm{q})\left(\text { 円 } / \mathrm{m}^{3}\right)
$$

式(4-1)から q(〈qo)における被害額は次式となる.

$$
\mathrm{D}(\mathrm{q})=\mathrm{a} / \mathrm{b} \cdot\{\exp (-\mathrm{b} \cdot \mathrm{q})-\exp (-\mathrm{b} \cdot \mathrm{qo})\}
$$


ここで,q:給水量 $\left(\mathrm{m}^{3} /\right.$ 人/日)、 $\mathrm{a}, \mathrm{b}$ : qo によって定まる定数 で,qo:0.4では $\mathrm{a}=734,700 、 \mathrm{~b}=22.26$ となる.

次に 河川の流況は,豊水流量までは線形で推移し,回 復勾配は最低流量で決まるとして $\mathrm{n}$ 年における $\mathrm{i}$ 番目の流 況 Qn(i)を次式で与えた.(図-5、図-6参照)

$$
\begin{aligned}
& \mathrm{Qn}(\mathrm{i})=\mathrm{Qn}(365)+(365-\mathrm{i}) \cdot \mathrm{QN}(365) / \mathrm{T} \\
& \mathrm{T}=1249 \cdot \mathrm{Qn}(365)^{-0.47}
\end{aligned}
$$

ここで, $\mathrm{Qn}(365): \mathrm{n}$ 年の最低流量 $\mathrm{T}$ :回復期間.

式(4-2),(4-3)よりn年における年間被害額 DL(n)は

次式で算定できる.

$$
\mathrm{DL}(\mathrm{n})=\mathrm{a} / \mathrm{b} \times\left(-\mathrm{b} \cdot \mathrm{qo}(1-1 / \mathrm{T}) \cdot\left[\left\{\exp \left(\mathrm{b} \cdot \mathrm{qo} \cdot \mathrm{r}_{\mathrm{n}}(365)\right)\right\}-1\right]\right.
$$

$$
/(\exp (\mathrm{b} \cdot \mathrm{qo} / \mathrm{T}-1))-100 \cdot \mathrm{r}_{\mathrm{n}}(365) \cdot \mathrm{T} / \mathrm{b}
$$

ここに, $\mathrm{r}_{\mathrm{n}}(365): \mathrm{n}$ 年の最大給水制限率

ここで, $\mathrm{r}_{\mathrm{n}}(365)$ の発生確率を $\mathrm{f}_{\mathrm{r}}\left(\mathrm{r}_{\mathrm{n}}\right)$, 流域人口を $\mathrm{P}$ とすると流 域の年平均被害額(断水少スク) $\mathrm{D}_{\mathrm{r}}$ は次式となる.

$$
\mathrm{D}_{\mathrm{r}}=\mathrm{P} \times \int \mathrm{DL}(\mathrm{n}) \times \mathrm{f}\left(\mathrm{r}_{\mathrm{n}}\right) \mathrm{dr}_{\mathrm{n}}
$$

図-5 は, 淀川の過去 20 年の流量デー劢ら求めた, 各 流況(豊,平,低,渴,最低)の発生確率別の流量を示す.

図-6 は,最低流量と渴水回復期間の関係を示す.

図-7 は,これらの関係式を用いて $100 \%$ 淀川に依存す る場合の取水制限率と渴水被害度の関係を求めたもので ある. ただし,流況及び過去の渴水害績より最大給水制限 期間は271日(365-95+1)とした。

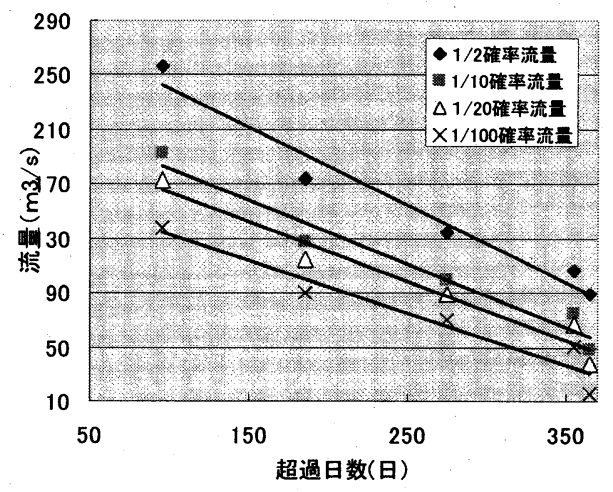

図-5 淀川（枚方）の流況

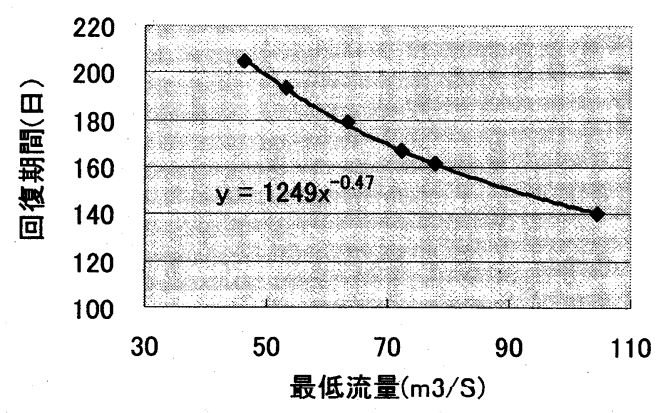

図-6 淀川における最低流量と回復期間

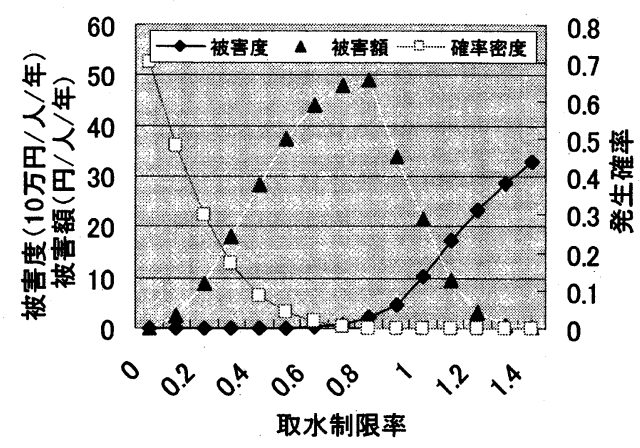

图-7淀川における取水制限と渴水被害度曲線

\section{b) 平常時事故断水リスク指標}

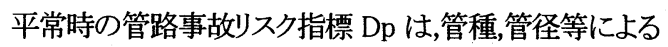
事故発生被害件数,被害度等より次式で算定した. ${ }^{34)}$

$$
D p=P f \times P p \times V p \times D i
$$

ここに,Pp:路線が受け持つ給水人口(人), $\mathrm{Vp}:$ 路線の復旧 速度 (日/件), Di: 1 人 1 日当たり断水被害額 (33千円/人) 日),Pf: 平常時の事故件数(件/年)で次式で与えられる.

$$
\mathrm{Pf}=\mathrm{Cf} \times \mathrm{Cp} \times \alpha
$$

ここに,Cf: 事故危険度係数,Cp:管径による補正係数, $\alpha:$ 事故断水率.

$\mathrm{Pp}($ 人)については,管径等による管路の流下能力より 施設稼働率や負荷率を考慮して設定した.

\section{c)地震断水被害リスク指標}

地震による断水被害指標Dpaは地震の発生確率と規模, 而震化状況,断水期間等より次式で算定した. ${ }^{3536)}$

$$
\mathrm{Dpa}=\mathrm{P} \times \mathrm{Y} \times \mathrm{Ld} / 2 \times \mathrm{Di} / 50 \text { 年 }
$$

ここに,P: 人口(人), Ld:断水期間(日),Di:被害原単位 (3.3 万円/日/人), $P \times Y \times L d / 2:$ 延べ被害人数(人・日), $\mathrm{Y}$ :初期断水率で算定は次式を用いた. ${ }^{35)}$

$$
\mathrm{Y}=1 /\left(1+0.0473 \mathrm{Rm}^{-1.61}\right)
$$

ここに, $\operatorname{Rm}(\beta)$ : 管路地震被害率, $\beta$ : 地震の最大加速度 で, $\mathrm{R}(\beta)$ : 標準被害率とすると次式で与えられる.

$$
\begin{aligned}
& \mathrm{Rm}(\beta)=\mathrm{Cp} \times \mathrm{Cd} \times \mathrm{Cg} \times \mathrm{C} 1 \times \mathrm{R}(\beta) \\
& \mathrm{R}(\beta)=2.88 \times 10^{-6} \cdot(\beta-100)^{1.97}
\end{aligned}
$$

ここに, $\mathrm{Cp}, \mathrm{Cd}, \mathrm{Cg}, \mathrm{Cl}$ は,管種,管径,地盤,液状化条件によ る係数. また,地震発生周期は 50 年とし,断水期間 Ld は, 水道管路の管種,管径別の延長と管路地震被害率より地 震による流域全体の被害件数 $\mathrm{Nd}$ を求め復旧速度 $\mathrm{Vd}$ 10 箇所 $/ 1$ 日として次式で求めた.

$$
\mathrm{Ld}=\mathrm{Nd} / \mathrm{Vd}
$$

\section{(2)安全性指標}

\section{a)発ガンリスクとクリプトスポリシュームによる感染リスク}

水道水質の健康师久は有害化学物質に起因寸るもの と病原性微生物に起因するものに類別される.ここでは, 
浄水処理で問題となっている,以八ロ㶴等による発ガン とクリプトスポリジュームによる発症によってもたらされる 人の健康被害等を基にリスクを算定した ${ }^{377}$. また水道 水質の安全性を金銭評価するため,WHO や世界銀行 が世界の疫病負担の総合的指標として公表した

DALYLs (障害調整生存年数) とその原単位 (0.1億円 /人) 388を用いた.

発ガンリスクは,水道水質で発ガンに関して閾值のない (1)ブロモジクロロメタン (WHO 勧告値 $0.06 \mathrm{mg} / \mathrm{L})$

(2)ジクロロ酢酸 (基準値 $0.04 \mathrm{mg} / \mathrm{L}$ )

(3)臭素酸(基準值 $0.01 \mathrm{mg} / \mathrm{L}$ )を評価対象とした.

夘プトス゚リジームリスク (Cpl)については,原水に含まれ るオ-汉卜個数と浄水処理性を基に, 浄水の污染確率を算 定し, 米国淤ォーキーにおける集団発生事例等より, 水道 水での検出が 1 個/10L の時 DALY S : $1.5 \times 10^{-4}$ とし, 沈殿ろ過で除去率は $2 \log$ 、オゾン・活性炭処理で $2 \log$ とした. なお,下水処理水については, 既往の調査 ${ }^{39)}$ 基に河川原水の 10 倍のオーシ外が含まれるものとした.

\section{b)水源水質事故リスク指標}

水源水質事故リスク指標は,水源水質事故の発生頻度と 取水停止,取水制限等による被害額を基に算定した. 淀 川での水質事故実績と流下時間より,発生頻度は 0.06 (3 回/50 年),取水停止期間 1 日とした. 水質事故での給水 制限による影響度は, 渴水被害と同じ水価值曲線式(4-2) より算定した.

\section{5. 地球環境指標}

地球環境指標として,地球温暖化の主な原因物質であ る $\mathrm{CO}_{2}$ 排出量と資源の枯渴が問題となっているエネルギ 一消費量を用いた. これらの数値の算定に当たっては, 「積み上げ法」と「産業連関分析法」によるL. C. Aの手法 を用いた. ${ }^{40)}$

\section{(1)建設段階}

建設段階の環境負荷排出量は,浄水場の建設,管路の 布設,設備の設置などに分け,費用関数(表-8)を用いて費 用を計算L,L.C.A 原単位(表-9)を用いて $\mathrm{CO}_{2}$ 排出量と工 ネルギー消費量へ変換した.

なお施設の耐用年数は法定耐用年数を基本とした.

\section{(2)運用段階}

水道統計 ${ }^{41)}$ 、下水道統計 ${ }^{42)}$ 等をもとに, 大阪府内の各水 道事業体, 下水処理場等の運用実績から各規模別の電力 消費量(表-11,表-12)や薬品使用量(表-10)の原単位を 求めてモデル流域に適用した.

\section{表 -8 費用関数}

\begin{tabular}{|c|c|}
\hline & $\begin{array}{c}\text { 対象施設 } \\
\text { 費用関数(95 年度価格·百万円) } 40)\end{array}$ \\
\hline \multirow{7}{*}{$\begin{array}{l}\text { 上 } \\
\text { 水 } \\
\text { 道 }\end{array}$} & 取導水施設 土木 $\quad 0.044 \times Q$ \\
\hline & 取導水施設 設備 $\quad 0.0067 \times Q$ \\
\hline & 浄水施設 土木 $73.9 \times(1.1 \times Q / 1000)^{0.915}$ \\
\hline & 浄水施設 設備 $31.7 \times(1.1 \times 0 / 1000)^{0.915}$ \\
\hline & $18.4 \times Q / 2000+32.8$ \\
\hline & 配水管 \\
\hline & $\left(7.79 \times 10^{-5} x^{2}+1.15 \times 10^{-1} x+24.7\right) \times L(X)$ \\
\hline \multirow{3}{*}{$\begin{array}{l}\text { 下 } \\
\text { 水 } \\
\text { 道 }\end{array}$} & 管渠 $\quad\left(40+0.14 \mathrm{x}+7.1 \times 10^{-5} \mathrm{x}^{2}\right) \times \mathrm{L}(\mathrm{X})$ \\
\hline & ポンプ場 \\
\hline & $588 \times(Q / 1000)^{0.719}$ \\
\hline \multicolumn{2}{|c|}{$\begin{array}{l}\text { Q:施設能力 }\left(\mathrm{m}^{3} / \text { 日 }\right) 、 \mathrm{x} \text { : 管径 }(\mathrm{mm}) \\
\mathrm{L}(\mathrm{x}) \text { : 管路延長 }(\mathrm{km}) 、 \mathrm{~N} \text { : 施設数 }\end{array}$} \\
\hline
\end{tabular}

\section{表-9 LCA 原単位}

\begin{tabular}{|c|c|c|}
\hline $\begin{array}{l}\text { LCA原単位 } \\
\text { (建設段階) }\end{array}$ & $\begin{array}{c}\text { エネルギー消費 } \\
\text { (TOE/百万円 })\end{array}$ & $\begin{array}{c}\mathrm{CO}_{2} \text { 排出 } \\
(\mathrm{t}-\mathrm{C} / \text { 百万円 })\end{array}$ \\
\hline 土木(上水道) & 1.00 & 1.05 \\
\hline 土木(下水道) & 0.914 & 1.00 \\
\hline 設備 & 1.10 & 0.98 \\
\hline \multicolumn{2}{|r}{$\mathrm{TOE}$ (石油換算トン) $=10^{7} \mathrm{kcal}$}
\end{tabular}

\begin{tabular}{|c|c|c|}
\hline (運用段階) & エネルギー消費 & $\mathrm{CO}_{2}$ 排出 \\
\hline 塩素剂 & $9.54 \mathrm{kcal} / \mathrm{g}$ & $299 \mathrm{~kg}-\mathrm{C} / \mathrm{t}$ \\
\hline 凝集剤 $(\mathrm{PAC})$ & $0.58 \mathrm{kcal} / \mathrm{g}$ & $299 \mathrm{~kg}-\mathrm{C} / \mathrm{t}$ \\
\hline 苛性ソーダ & $7.23 \mathrm{kcal} / \mathrm{g}$ & $178 \mathrm{~kg}-\mathrm{C} / \mathrm{t}^{1}$ \\
\hline 電力 & $2250 \mathrm{kcal} / \mathrm{kWh}$ & $0.104 \mathrm{~kg}-\mathrm{C} / \mathrm{kWh}$ \\
\hline
\end{tabular}

表-10 浄水薬品使用量

\begin{tabular}{|l|r|r|r|}
\hline & $\begin{array}{l}\text { 塩素剂 } \\
\left(\mathrm{kg} / \mathrm{m}^{3}\right)\end{array}$ & \multicolumn{1}{|c|}{$\begin{array}{l}\text { 凝集剂 } \\
\left(\mathrm{kg} / \mathrm{m}^{3}\right)\end{array}$} & $\begin{array}{l}\text { 苛性ソーダ } \\
\left(\mathrm{kg} / \mathrm{m}^{3}\right)\end{array}$ \\
\hline 府内市町村 & 0.0174 & 0.026 & 0.0077 \\
\hline 府営水道 & 0.0104 & 0.031 & 0.0041 \\
\hline
\end{tabular}

表-11 浄水給水規模別電力原単位

\begin{tabular}{|c|c|c|c|}
\hline $\begin{array}{l}\text { 給水規模 } \\
\left(\text { 万m }{ }^{3}\right)\end{array}$ & $\begin{array}{l}\text { 原 単 位 } \\
\left(\mathrm{kWh} / \mathrm{m}^{3}\right)\end{array}$ & $\begin{array}{l}\text { 給水規模 } \\
\left(\text { 万的 }{ }^{3}\right)\end{array}$ & $\begin{array}{l}\text { 原 単 位 } \\
\left(\mathrm{kWh} / \mathrm{m}^{3}\right)\end{array}$ \\
\hline 30 以上 & 0.452 & $5 \sim 3$ & 0.335 \\
\hline $30 \sim 10$ & 0.226 & $1 \sim 3$ & 0.430 \\
\hline \multirow[t]{2}{*}{$10 \sim 5$} & 0.252 & 1 以下 & 0.616 \\
\hline & & 府営水道 & 0.741 \\
\hline
\end{tabular}


表-12 下水処理規模別電力原単位

\begin{tabular}{|c|c|c|c|}
\hline $\begin{array}{l}\text { 下水規模 } \\
\left(\text { 万m }{ }^{3}\right)\end{array}$ & $\begin{array}{l}\text { 原単 位 } \\
\left(\mathrm{kWh} / \mathrm{m}^{3}\right)\end{array}$ & $\begin{array}{l}\text { 下水規模 } \\
\left(\text { 万 }{ }^{3}\right)\end{array}$ & $\begin{array}{l}\text { 原 単 位 } \\
\left(\mathrm{kWh} / \mathrm{m}^{3}\right)\end{array}$ \\
\hline 10 以上 & 0.369 & $3 \sim 0.1$ & 0.594 \\
\hline $10 \sim 5$ & 0.405 & 0.1 以下 & 1.249 \\
\hline $5 \sim 3$ & 0.466 & & \\
\hline
\end{tabular}

なお污泥の処分については考虑していない.

環境負荷の金額評価に関しては,エネルギーは量ととも にその質が重要とされることから,最も質の高いエネルギ 一源の一つである電力費 $(11$ 円/kwh)に換算して指標とし た. $\mathrm{CO}_{2}$ については,わが国での6\%削減を害現するため に必要な炭素税額 3 万円/t-C を用いた.43)

\section{6.ライフサイクルコスト(LC.C)}

L.C.Cの算定は,建設費についてはL.C.Aの建設段階 で費用関数を用いて求めた1995年時点の価格を,デフレ 一夕を用いて2003年の単価に変換した. また,運用費に ついては,L.C.A で求めた使用量と,2003 年の使用単価実 績から求めた.

ただし,ここでは水源開発,污泥処理,廃棄は含めていな い. また,総合評価にあたっては運用と重複する地球環境 指標のエネルギー分を減じた。

\section{7. モデル流域の設定}

河川の水質に課題を抱える大和川支川で水道水源とな っている西除川流域(図-8)を参考に図-9、表-13に示 す流域モデルを設定した. (以下これを N 流域と称する)

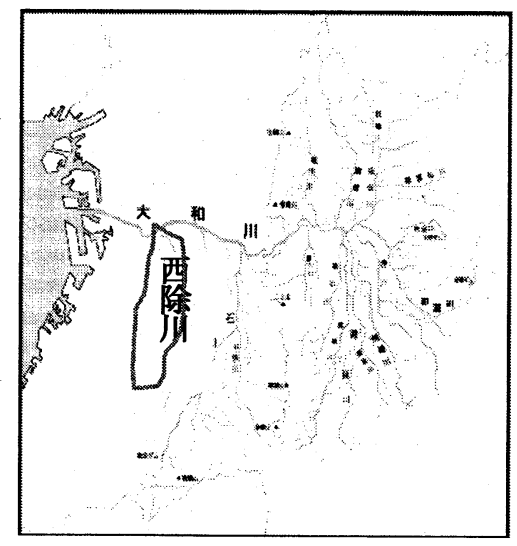

図-8モデル流域位置図

\section{（1）N 流域モデル}

GIS データ4445) と市町村の統計資料等 24)25)26)を基に現況 流域の土地利用, 人口,水道供給量, 下水道整備率等を設
定した. また大阪管区気象台観測データ46)等を基に,降 雨量,気温,地盤高等を設定した.(表-13)

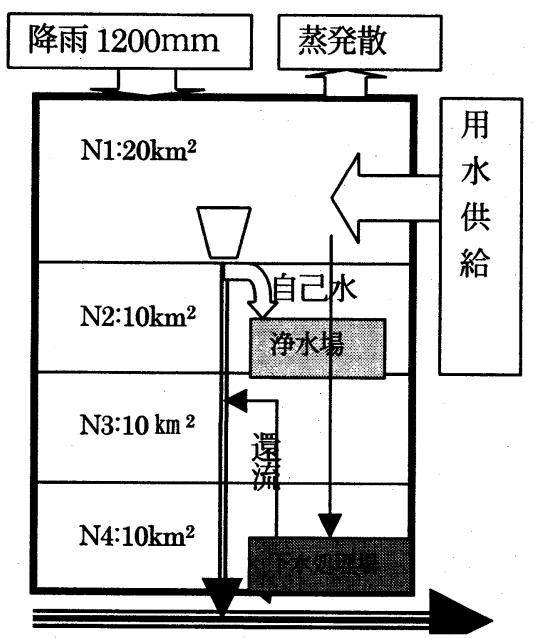

图-9 N 流域模式図(ケ-ス 1-1)

表-13 N 流域の河川流域諸元

\begin{tabular}{|c|c|}
\hline 人口 : 25 万人 & 水道水給水量 10 万 $\mathrm{m}^{3} /$ 日 \\
\hline 流域面積 : 50km² & 下水道 : 分流式 \\
\hline 森林： $6 \mathrm{~km}^{2}$ & 下水道:整備率 $70 \% \Rightarrow 100 \%$ \\
\hline 農地： $10 \mathrm{~km}^{2}$ & 合併浄化槽 $10 \%$ \\
\hline 宅地： $20 \mathrm{~km}^{2}$ & 単独浄化槽 $10 \%$ \\
\hline 水面 : $4 \mathrm{~km}^{2}$ & し尿処理 $\quad 10 \%$ \\
\hline 道路： $4 \mathrm{~km}^{2}$ & 河川 : 延長 12km \\
\hline その他 : $6 \mathrm{~km}^{2}$ & 絴断勾配 1/500～1/250 \\
\hline 降雨量 : $1200 \mathrm{~mm} /$ 年 & 川幅 20～10m(天端 3m) \\
\hline 平均気温 : $16.5^{\circ} \mathrm{C}$ & 法面勾配 5\%（ブ ロック張） \\
\hline & 治水レベル $\quad 1 / 10$ \\
\hline
\end{tabular}

\section{(2)検討ケース}

モデル流域は 4 流域に分割し, 以下に示す各ケースで 検討した. 現況（ケ-ス0）の下水道の整備率は 70\%であ るが, 各検討ケ-スではこれが 100\%整備されるとした.

ケ-ス 1 : 現状の上下水道システムを継続

ケ-ス 1-1 : 現状システムで下水処理水を河川に還流

ヶ-ス 1-2 : 流域内雨水を循環利用し自立分散型へ移行

ケ-ス 2 : 流域外から全て給水するシステムに移行

ヶース 3 : 用水供給 100\%で下水還流水を河川に還流

各ケ-スの給水内訳と下水処理水還流量を表-14 に示す.

ここで, 用水供給とは, 他流域から長距離導水管路を通 じて供給される水道水. 自己水とは, 流域内で水源を確 保し処理して供給する水道水としている.

ケ-ス 1-2 では, 下水処理水を河川に還流することによ り,自己水で $100 \%$ まかなうこととしている. 
表-14 ケ-別給水量・還流水量の内訳（単位: 万 $\mathrm{m}^{3}$ /日）

\begin{tabular}{|c|c|c|c|c|}
\hline & \multicolumn{2}{|c|}{ 水道給水量 } & \multirow{2}{*}{$\begin{array}{c}\text { 下水道 } \\
\text { 還流水量 }\end{array}$} \\
\hline & & 用水供給 & 自己水 & \\
\hline \multicolumn{2}{|c|}{ ケ-ス0 } & 8 & 2 & 0 \\
\hline 検 & 1 & 8 & 2 & 0 \\
\hline 討 & 1-1 & 8 & 2 & 6 \\
\hline ケ & $1-2$ & 0 & 10 & 10 \\
\hline 1 & 2 & 10 & 0 & 0 \\
\hline ス & 3 & 10 & 0 & 4 \\
\hline
\end{tabular}

\section{(3)上下水道施設の配置}

\section{a)净水場、下水処理場}

下水処理場は, 現状を参考に流域最下流に一箇所配置, 浄水場については,ケ-ス1-2 は, 下流 3 流域に分散配置, そ の他は現状を参考に 1 籄所配置した.（図-9参照）

\section{b)上下水道の呑管網}

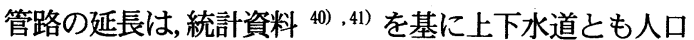
密度と配管密度との関係式より設定した.（図-10,图-11） 上水道の管径,管種については, 大阪府下各市町村の規模 別の内訳 40) 等を基に設定した.

下水道の污水管の管径については, 下水道統計には規 模別内訳が記載されていないため, 文献 ${ }^{47)}$ を基に河川の 分岐則(地形則)を適用して規模別の管径内訳を設定した

（図-12）．なお下水処理水の還流施設については, 流量 及びポンプ揚程等を基に設定した.

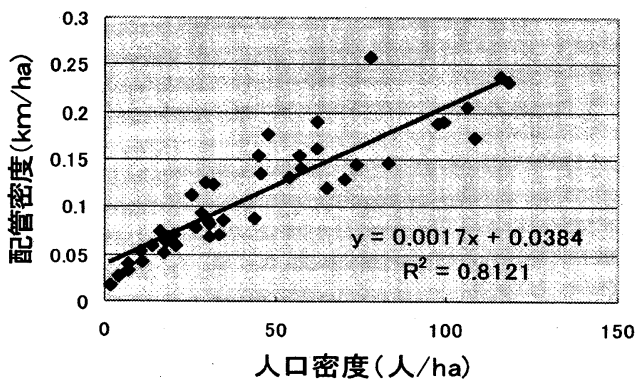

図-10 水道配管密度と人口密度の関係

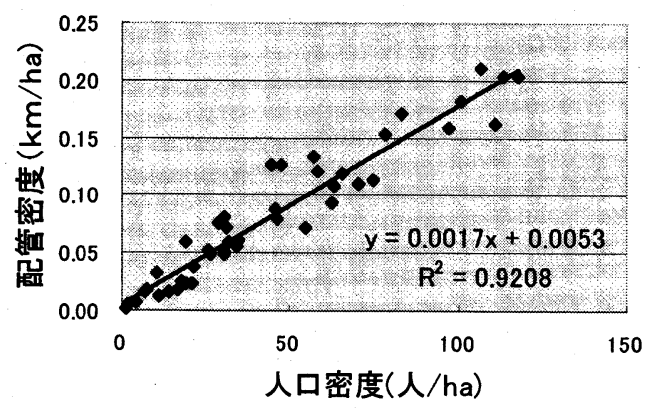

图-11 下水道配管密度と人口密度の関係

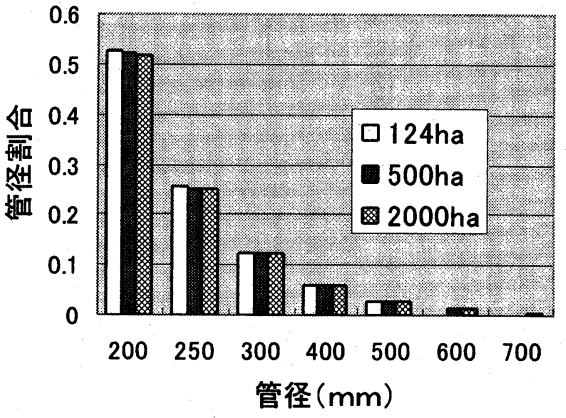

图-12 下水道配管の管径割合（地形則より）

表 - 15 上下水道管渠の内訳

\begin{tabular}{|l|l|}
\hline $\begin{array}{l}\text { 水道管渠 } \mathrm{L}=610 \mathrm{~km} \\
\text { 最大口径 } \Phi=700 \mathrm{~mm}\end{array}$ & $\begin{array}{l}\text { 下水道管渠 } \mathrm{L}=460 \mathrm{~km} \\
\text { 最大口径 } \Phi=900 \mathrm{~mm}\end{array}$ \\
\hline
\end{tabular}

\section{8. 計算結果}

$\mathrm{N}$ 流域での河川流量・水質と各指標值の計算結果を図 13 〜図 18に示す. 各指標値は,流域指標を除き 1 年間当たり に流域内に住民が受けるリスクや被害度を金銭で評価した ものであり,流域の水環境にとつて望ましくない状況の程度 を表したもので貨幣価值はマイナス (一億円/年)で評価さ れる. 流域指標については,表-7に示す自然休養機能など 流域の持つ望ましい環境価值であり,その貨幣価值はプラ ス(億円/年)で評価されることになる.

これらの貨幣指標值を全て合計したものを「流域水資産 健全度指数」と定義しこれが流域としての総合評価指標と なる.

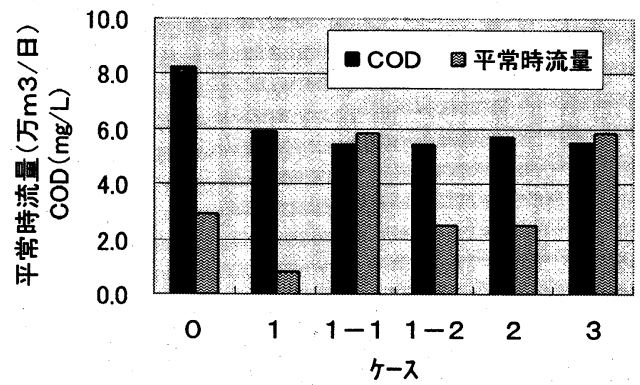

図-13 河川流量・水質計算結果

（1）河川・流域指標（図-14,15）

ケ-ス 1 では, 現状から下水道の整備が進み, 水質は改善 されるものの, 平常時流量が減じ, その効果は相殺される

（図-13）.下水の処理水を河川に還流するケ-ス 1-1,ケ-ス 3 では平常時の流量が大幅に改善され指標値も向上す 
る. ケース1-2,ケ-ス 2 では, 平常時の流量が若干減少し指標 值も低下する．流域指標については, 今回の検討では条 件に変化はなく指標值にほとんど変化はなかった

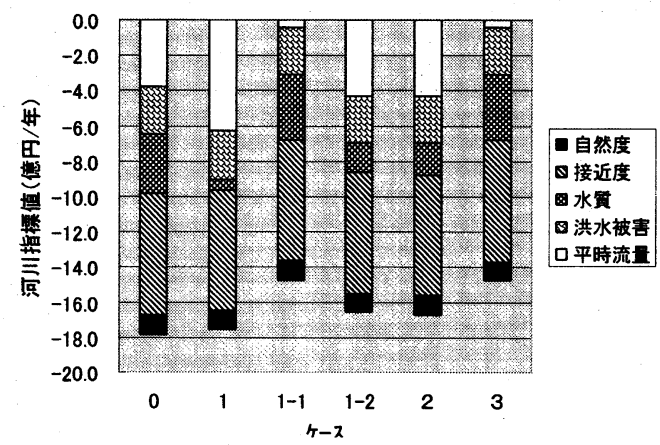

图-14 河川指標計算結果

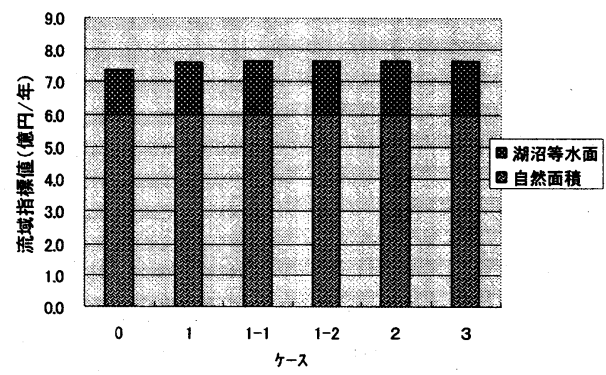

図-15 流域指標計算結果

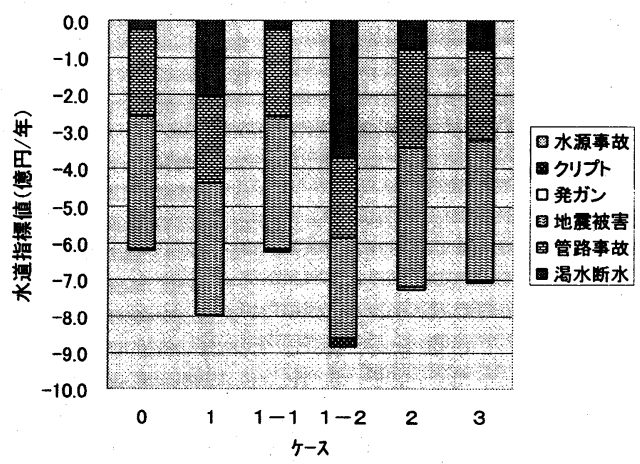

图-16 水道指標 計算結果

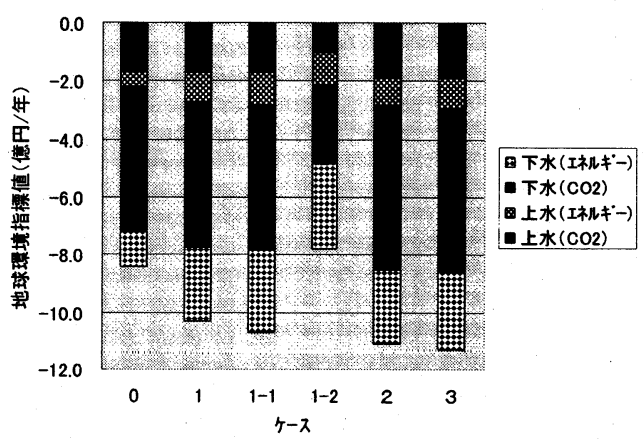

图-17 地球環境指標 計算結果

\section{(2)水道指標 (図-16)}

いずれのケースにおいても現状に比べ被害度は増大 した. 特に,ケース1、1-2では晹水被害度が増大し,用水供 給に $100 \%$ 頼るケース2,3では渴水と地震被害リスクの増 大が見られた.

\section{(3)地球㻴境指畨（图-17）}

上水道に関しては,現在のシステムと同じケース1, 1-1に 変化はないが,ケース2,3では,遠距離送水が増大するこ とから，環境負荷は増大し指標值は悪化，逆に自己水源に たよるケース1-2では向上した.

下水道では,整備の進渉や高度処理の導入によりいず れのケースにおいても,環境負荷が増大し,現状より指標 值は悪化した. ただし,今回は下水道の公衆衛生面での 効果は加味していない.

\section{(4)ライフサイクルコス(図-18)}

いずれのケースも睘境指標と同様な傾向が見られた 特にケ-ス 1-1,1-2,3 では,処理水の還流施設分のコストが 上乗せされる結果となった

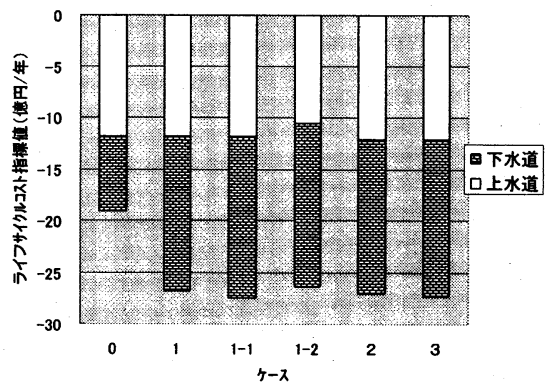

図-18ラ伊州仍玒不指標 計算結果

\section{N流域での総合評価と考察}

N流域の各指標を各ケース別に集計した総合評価結果 「流域水資産健全度指数」を表-16に示す。

表-16 N 流域での総合評価結果(単位:億円)

\begin{tabular}{|c|c|c|c|c|c|c|}
\hline ケース & O & 1 & $1-1$ & $1-2$ & 2 & 3 \\
\hline 河川流域 & -10.5 & -10.0 & -7.1 & -8.9 & -9.1 & -7.1 \\
\hline 水道指標 & -6.2 & -8.0 & & -8.8 & -7.3 & -7.1 \\
\hline 地球環境 & -8.4 & -10.3 & -10.7 & -7.8 & -11.1 & -11.3 \\
\hline 小計 & -25.1 & -28.3 & -24.0 & -25.5 & -27.4 & -25.5 \\
\hline LCC & -19.1 & -26.8 & -27.5 & -26.5 & -27.1 & -27.3 \\
\hline 総合計 & -44.2 & -55.0 & -51.5 & -52.0 & -54.5 & -52.9 \\
\hline
\end{tabular}


これによれば,河川流域指標と水道指標ではケース 1-1 が,地球環境指標と L.C.C ではケース 1-2 が高く評価され， 総合評価(流域水資産健全度指数)では,下水処理水を河 川に還流するケース 1-1 が最もが高く評価された.

以上の結果より,N流域での上下水道システムに関して は,今後の下水道整備により,現状のシステム(ケース1)では, その効果は平常時流量の減少で相殺され,渴水少スク 地球環境への負荷の増大などで,「流域水資産健全度」は 大きく低下寸る. その対応策として,下水高度処理水の河 川への還流(ケース1-1)や自己水源にすべて依存するシス テム(ケース1-2)の導入,さらに逆に自己水源を廃止して他 流域からの水源に全て依存するシステム(ケース2-1)への 移行が考えられるが,今回の計算では,現在のシステムで 下水処理水を河川人還流するケース1-1が最も高い評価と なった. しかし、水源を他流域に頼らない自律分散型のケ 一ス1-2や100\%用水供給に依存するケース3との差は,大き なものではなく,地球温暖化対策といら視点に立てば地球 環境への影響の最も少ないケース1-2への移行の必要性も 考えられる.

なお,今回の評価では,貨幣価値を用いたが,これについ ては,環境や生命の価値を金銭で評価することの可否や 割引率の扱い等研究者の間でもまだ議論の多いところで ある. また, $\mathrm{CO}_{2}$ の貨幣評価についても地球温暖化は深 層海流の停止など破局的な影響の発生を考え, 気温上 昇を抑止する噮境税額で評価したが, 他の研究 ${ }^{38)}$ では 具体的な健康や経済的被害額での評価も行われている. またエ神ギ -についても, 最も質の高い電力の現在価格 で評価したが, 資源の不足が予想される次世代でも現 在単価で評価すべきかどうかの議論も考えられる.さ らに、水循環やLCAなどの個々のテーマが大きな研究課 題であり,より精度の高い評価はそれらの研究成果を 待つ必要がある. しかしながら地球温暖化は確実に進 行しており,わが国の人口減少, 上下水道施設の老朽化 も確実に進行することから, 今まさに早急な対応, 具体 的な行動が求められている.こうしたことから, 今回は, 今後の上下水道システム再構築の方向性を評価する指 針づくりを目指し,汎用性や住民へのわかり易さを基 本とした総合評価手法を提案したものである.

\section{0. おわりに}

持続可能性には種々な定義があるが,持続可能な発展 とは,一般に[環境]、[社会]、[経済]が調和した発展とされ ている. 本文は、持続可能な上水道システム評価のために 環境として地球環境や水循環、社会として水道の安全性・ 安定性、経済としてLCCを抽出し,それらを貨幣価値で総
合的に評価する「流域水資産健全度指数」を提案し,N流 域モデルでの上下水道システムの評価を試みた.

これによれば,比較的人口密度の高いN流域モデルでは, 用水供給に依存する現状のシステムで,下水処理水を河 川に還流するケースがもつとも高い評価となった. 一方、地 球環境といら視点では用水供給に依存しない自立分散型 が望ましいとの結果も得た。

今回の検討では, 今後の社会的, 自然的条件の変化,下 水道事業の効用, さらに浄水処理手法の変更等は考慮 していない，また, 水源や人件費の評価なども考虑し ていない.今後,更に詳細な資料データを収集し,地球温 暖化や人口減少の影響,他の流域や流域対策の効果の 検討などを追加し,上下水道の再構築の方向性,また水循 環から見た流域の望ましい姿などを評価する手法として 発展させていきたい.

\section{考文献}

1) 環境省:総合的環境指標について環境基本計画における指 標のあり方に関する調查検討会参考資料.2006

2) 産業技術総合研究所:LCAのケーススタディ(三重県,千葉県,岩 手県におけるLCA手法の研究開発),2005

3)日本水道協会:水道事業ガイドライン(JWWA Q100),2007 4)木山正一:澴境·経済統合勘定を適用した流域水環境の実態把 握と将来型管理計画への一考察,環境システム研究論文集,Vol 34,2006

5)氏原岳人,谷口守・古米弘明・小野芳朗:ウォータサプライ・フット プリント指標を用いた都市活動配置評価一水利用·循環の視点か ら地区整備を考える一,環境ンステム研究論文集,Vol 34,2006 6)多田律夫・三浦浩之・和田安彦他:分散型水供給システムのエコ デザインによる評価,環境ンステム研究論文集,Vol.28,2000

7)霹巻峰夫:水環境関連分野でのLCA適用の試み，水環境学会 誌,Vol23,No.2,2000

8)近藤博幸,藤原正弘,中村洋,滰沢智: 浄水施設を対象としたライ フサイクルアセスメント関する研究,全国水道研究発表会講演 集,pp.84-85,2007

9)岩竹貴則,馬場啓輔,市川浩:アセットマネジメトを適用した浄水 施設の更新計画事例,全国水道研究発表会講演,pp.60-61,2007 10)サステナビリティの科学的基䃈に関する調查プロジェタト:サ ステナビリティの科学的基䃈に関する調查報告書,2006

11) 環境庁: 環境白書,2000

12)厚生労働省: 水道ビジョン,2002

13)健全な水循環系構築に関する関倸省庁連絡会議: 健全な水循 環系構築のための計画づくりに向けて, 2003

14)国土交通省:今後の河川水質管理の指標について(案), 2005

15) 地方公営企業経営研究会: 地方公営企業年鑑,(財)地方財 政協会,2003 
16) 平山晴章:琵琶湖淀川における土地利用変化を考慮した窒 素負荷流出に関する研究:京都大学修士論文,pp.26,2003.

17)三浦浩之,和田安彦,多田律夫,尾崎 平 : 下水処理水還流汣 テムの環境調和性に関する研究, 土木学会論文集; No.629/VII $-12, p p .57-66,1999$.

18) 大阪府水道部: 大阪府水道用水供給事業の水需要予測結 果,pp.29,2005

19）日本下水道協会 : 流域別下水道整備総合計画調査指針と 解説, 1999.

20)(財)琵琶湖・淀川水質保全機構:琵琶湖・淀川水環境改善対 策総合調査報告書,p234,2000.

21)大阪府水道部:水質試験成績並びに調査報告,2003

22) 農林水産省:H17 食料,農業,農村白書,p107,2006

23)国土交通省:水資源白書,p107,p29,2006

24)大阪府士木部: 大阪府の雨量第 8〜 10 集

25)河内長野市:河内長野市統計書,2006

26) 大阪府建築都市部:国土計画関係資料集 (土地利用現況), 2005

27)大阪府企画調整部:H15 大阪府統計年鑑,2004

28）大阪府土木部:大阪府流量観測報告,1986-2005

29) 大阪府: 大阪府域河川等水質調查結果報告書

30) 土木学会:水理公式集H11 年版, p37

31) 大阪府下水道課:H18下水道統計, p274

32）日本ダム協会:ダム年鑑，p593,2002

33)日本学術会議答申:地球環境・人間生活にかかる農業及び森

林の多目的評価について(付表), 2001.
34）（社）日本水道協会 : 水道施設更新指針,p109-111,2005.

35) 水道産業新聞社: 全国 446 都市の水道の地震安心度評価,p9, 2003.

36)日本水道協会:地震による水道管路の被害予測,p54-56, 1998. 37)斉藤方正,木村昌弘,伊藤禎彦: DALYによる水道水質リス ク評価, 第58回全国水道研究発表会講演集, p716-717, 2006.

38）伊坪徳宏, 稲葉敦 : ライフサイクル影響評価手法,社団法 人 産業環境管理協会, p350,2005.

39)諏訪守, 鈴木穣 : 下水および河川水における夘プトスポジュ - の実態調査,土木技術資料,40-9, p50-55,1998

40）伊藤禎彦,千田祐一郎：流域における小規模分散型水供給 システム導入可能性の解析,日本水環境学会年次講演会集 p419,2005.

41）日本水道協会:H15 水道統計(行政編)

42）日本下水道協会:H15下水道統計(行政編)

43)環境庁 : 地球温暖化システム検討会第 2 次中間報告書, 1994.

44)国土交通省国土計画局: 国土数値情報, L03-09M-27, W07-52M

45)総務省統計局:地域メッシュ統計(H12)

46)気象庁:気象統計情報 (大阪年ごとの值),2007

47)田中修司(執筆代表者):下水道管渠学,環境新聞社,p37-41

\title{
A COMPREHENSIVE EVALUATION FOR ESTABLISHING SUSTAINABLE WATER AND SEWAGE SYSTEMS
}

\author{
Masahiro KIMURA Sadahiko ITOH
}

\begin{abstract}
We proposed a new comprehensive evaluation index for the water and sewage systems including preservation of global environment, soundness of water cycle of a basin, stability and safety of water service and performed this evaluation in a model basin. . The result of this comprehensive evaluation indicated that the recirculation of treated waste water to upstream was the best option among the five scenarios evaluated in this study. Also, decentralized water and sewage systems were found to be most effective for the prevention of global warming.
\end{abstract}

